\title{
Politics meets healthcare? Religious misinformation in India during the COVID-19 pandemic
}

\author{
Md. Sayeed Al-Zaman \\ Department of Journalism and Media Studies, Jahangirnagar University, Savar, Dhaka-1342, \\ Bangladesh. \\ msalzaman@juniv.edu
}

Received: 05/12/2020.

Reviewed: $18 / 12 / 2020$

Published: 31/12/2020.

Copyright $\odot 2020$ by the author (et al) and Jurnal Sosial Humaniora (JSH)

*This work is licensed under the Creative

Commons Attribution International License $(\mathrm{CC}$

BY 4.0).

http://creativecommons.org/licenses/by/4.0/

\section{Open Access}

\begin{abstract}
Subject Area: Communication
Abstract

India has recently become a hotspot of misinformation: the COVID-19 brings a new opportunity for the rumor-spreaders. Of various categories, religious misinformation seems harmful for both Indian society and public health. In this paper, therefore, I tried to sketch a few necessary aspects of religious misinformation in India during the COVID-19. From the previous literature and ongoing trend of Indian misinformation, I identified two important phenomena: (a) Though Muslims produce more spiritual misinformation, most of the religious misinformation targeting Muslims is inspired by Islamophobia; (b) misinformation that tries to champion Hinduism is more related to the contemporary political ideologies of India. I also tried to explain how religion as a political issue relates to public health
\end{abstract}

Keywords: COVID-19 pandemic; misinformation; social media; India; politics; healthcare.

\section{Introduction}

The World Health Organization (WHO) indicated the development of an infodemic (i.e., information pandemic) at the beginning of the COVID-19 pandemic. While true and reliable information helps to ameliorate the pandemic situation, false and misleading information exacerbates it. COVID-19 misinformation has become commonplace around the world, rewarding people with a lot of miseries, including killing people (Islam et al., 2020). Like many other countries, India has been suffering from a countrywide COVID-19 misinformation crisis that is hampering public health communication (Purohit, 2020; Sahoo, 2020). With 8.48 million infected and 0.13 million dead, India is still enduring the bitterness of the pandemic. In such circumstances, misinformation brought new tensions (Worldometer, 2020). Although medication, politics, and conspiracy theories are a few popular themes of COVID-19 misinformation in India (Sutaria, 2020), proliferating religious misinformation surpasses others in terms of impacts and poses a threat to both social integration and public health services 


\section{Religious misinformation in India}

Indian misinformation during the pandemic can be categorized into two types: medical and communal (Sutaria, 2020). Medical misinformation, including fake prescription and fake medicine, usually causes health hazards to individuals and increases the sale of medical products (ToI, 2020). For example, misinformation that suggests drinking alcohol can cure coronavirus could be detrimental for health. While medical misinformation is directly linked to public health, communal misinformation is more related to politics. Two major religious communities in India - Hindus and Muslims - produce most of the religious misinformation. In this context, however, two things are imperative to mention: (a) Though Muslims produce more spiritual misinformation, most of the religious misinformation targeting Muslims is inspired by Islamophobia; (b) misinformation that tries to champion Hinduism is more related to the contemporary political rhetoric in India. Important to note that some religious misinformation is not directly linked to the pandemic; rather, it shapes the public psyche and indirectly interrupts healthcare and public health communication.

Inspired by the pandemic situation, communal misinformation against Muslim minorities grows and incites interreligious discontents, widening more the historically unsettled rift between Hindus and Muslims. Muslims in India have been suffering from an adverse religious climate for the past few years, and the recent wave of communal misinformation degenerates the situation (Apoorvanand, 2020). For example, anti-Muslim misinformation like "Muslim vendors are spreading coronavirus in Surat" and "Muslims lick utensils to spread coronavirus" (for more, see Table 1) criminalizes Muslims, which often lead to their social deprivation and even healthcare denial (Partha, 2020). Note that Islamophobic misinformation in India is an old phenomenon. More than a hundred people were killed by the angry mobs in the last few years (Arun, 2019). A few groups of self-proclaimed custodians of Indian culture and religion promote such cruelty, and gau rakhshaks (cow vigilantes) are the most prominent of them. They produce and distribute misinformation against Muslims to trap and beat them (Mukherjee, 2020). Therefore, antiMuslim misinformation in India during the COVID-19 is nothing new, rather a new version of the old communalism that springs up once again capitalizing on the present pandemic.

Besides anti-Muslim misinformation, some misinformation mostly produced by Muslims tries to champion the significance of Islam, providing false and/or misleading narratives. For example, Islamic prayers can eradicate coronavirus, the Chinese are converting into Muslims, and COVID-19 is a curse from Allah are unscientific and misleading claims that try to promote Islamic virtues. The Bhartiya Janata Party (BJP) allegedly inspires a Hindu revivalism in India, repressing the Muslim minorities. During the pandemic, BJP's political rhetoric in favor of Hindutva (the regime of Hindus) gains a new momentum. Pro-Hindutva political figures and organizations misleading people try to popularize gau mutra (cow urine) as a cure for coronavirus. Even Akhil Bharat Hindu Mahasabha (All India Hindu Union), an India-based organization of Hindu activists, hosted a party for drinking cow urine to prevent COVID-19 (DW, 2020). Like Islamic misinformation, such misinformation is also unscientific, though many Indian politicians and the public defend it. 
In promoting pro-Hindu narratives for the Hindu nationalists, the internet has been used as a great networking tool. The penetration of the internet, as well as social media in India, is much higher than the other South Asian countries (Sahoo, 2020; “Social Media Stats India," 2019). Besides, BJP's "digital army" has been working in favor of the Hindu nationalist government for the past few years (Chaturvedi, 2016). Also, their digital archiving of pro-Hindutva history is a remarkable achievement in championing a Hindu revivalism in India (Udupa, 2017). Amid such a situation, with the lower level of media and internet literacy (Raj \& Goswami, 2020), a large number of Indian internet users might be vulnerable to the persuasive proHindutva political rhetoric. Therefore, like the previous point, we see that Hindutva has been present in Indian society before the pandemic came, and it gets a new occasion to flourish once again. Also note that the recent initiatives (e.g., Citizenship Amendment Act (CAA) and the National Register for Citizens (NRC) in Assam) taken by the government and supported by many pro-government citizens endorsed the ongoing anti-Muslim and pro-Hindu attitude in India during the pandemic (Apoorvanand, 2020; Sarkar, 2020).

\section{Conclusion}

To conclude, religious misinformation is increasing not only in India but also in Bangladesh, India's next-door neighbor (Al-Zaman et al., 2020). Also, COVID-19 religious misinformation is not an exclusive Indian problem, rather it is commonplace in the Middle East and North Africa (MENA) and Latin America as well (Alimardani \& Elswah, 2020; Longoria, Ramos, \& Webb, 2020). However, unlike the other regions, vitriol and political rhetoric are used against religious minorities in India, perhaps to achieve definite political agendas, which is somewhat unique: herein, politics meets healthcare. Thus, it is disturbing both public healthcare amid the pandemic and social integration of the Indian society. Unfortunately, efforts from the government to mitigate the crises are yet to come (Funke \& Flamini, 2019).

\section{References}

Al-Zaman, M. S., Sife, S. Al, Sultana, M., Akbar, M., Ahona, K. T. S., \& Sarkar, N. (2020). Social Media Rumors in Bangladesh. Journal of Information Science Theory and Practices, 8(3), 77-90. https://doi.org/10.1633/JISTaP.2020.8.3.6

Alimardani, M., \& Elswah, M. (2020). Online Temptations: COVID-19 and Religious Misinformation in the MENA Region. Social Media + Society, 6(3), 205630512094825. https://doi.org/10.1177/2056305120948251

Apoorvanand. (2020, April). How the coronavirus outbreak in India was blamed on Muslims.

Arun, C. (2019). On WhatsApp, Rumours, and Lynchings. Economic and Political Weekly, 54(6), 30-36.

Chaturvedi, S. (2016). I am a Troll: Inside the Secret World of the BJP's Digital Army. Juggernaut Publication.

DW. (2020, March). Hindu group hosts cow urine drinking party to ward off coronavirus. $D W$.

Funke, D., \& Flamini, D. (2019). A guide to anti-misinformation actions around the world. New York, 
USA.

Islam, M. S., Sarkar, T., Khan, S. H., Mostofa Kamal, A.-H., Hasan, S. M. M., Kabir, A., ... Seale, H. (2020). COVID-19-Related Infodemic and Its Impact on Public Health: A Global Social Media Analysis. The American Journal of Tropical Medicine and Hygiene, tpmd200812. https://doi.org/10.4269/ajtmh.20-0812

Longoria, J., Ramos, D. A., \& Webb, M. (2020, September). In Latin America, religious misinformation on Covid-19 spreads with the help of the Christian press.

Mukherjee, R. (2020). Mobile witnessing on WhatsApp: Vigilante virality and the anatomy of mob lynching. South Asian Popular Culture, 18(1), 79-101. https://doi.org/10.1080/14746689.2020.1736810

Partha, M. (2020, April). India hospital segregates Muslim and Hindu coronavirus patients. Al Jazeera.

Purohit, K. (2020, March). Misinformation, fake news spark India coronavirus fears.

Raj, A., \& Goswami, M. P. (2020). Is fake news spreading more rapidly than COVID-19 in India? Journal of Content, Community and Communication, 11(10), 208-220. https://doi.org/10.31620/JCCC.06.20/15

Sahoo, N. (2020, May). How fake news is complicating India's war against COVID-19.

Sarkar, S. (2020). Religious discrimination is hindering the covid-19 response. BMJ (Clinical Research Ed.), 369, m2280. https://doi.org/10.1136/bmj.m2280

Social Media Stats India. (2019, August). StatCounter.

Sutaria, S. (2020). Coronavirus Misinformation in India Is Not Limited to Health Misinformation. Delhi, India.

ToI. (2020, July). Coronavirus myth vs. fact: WhatsApp forward claiming turmeric and black pepper home remedy to cure COVID-19 is fake. Times of India (ToI).

Udupa, S. (2017). Viral video: mobile media, riot and religious politics. In S. Udupa \& S. D. McDowell (Eds.), Media as politics in South Asia (pp. 190-205). Milton Park, Abingdon, Oxon ; New York, NY: Routledge.

Worldometer. (2020, November). India Coronavirus: 8,478,689 Cases and 125,895 Deaths. 
Table 1. A few examples of religious COVID-19 misinformation in India

\begin{tabular}{|l}
\hline Claims of misinformation \\
Islamic misinformation \\
"Islamic prayers to get rid of coronavirus." \\
"Reciting the Quran to stay safe from coronavirus." \\
"Trump offers Islamic prayers amid Corona." \\
Anti-Muslim misinformation \\
"Muslim vendors are spreading coronavirus in Surat." \\
"Tablighi Jamaat member roaming naked in isolation ward." \\
"A Hindu man was murdered by a Muslim man in Rajasthan." \\
"Muslim man injecting fruits with spittle to spread coronavirus." \\
"Muslims licking utensils to spread coronavirus." \\
Pro-Hindu misinformation \\
"Cow urine to curb coronavirus infection." \\
"Ramdev overdosed on cow urine to avoid coronavirus." \\
"Chinese monks sprinkling cow urine to curb coronavirus infection." \\
"Vinayaka temple converted into a quarantine center." \\
Note. The claims of misinformation were collected in February-July 2020 from Alt News \\
(http://altnews.in), a fact-checking website certified by the International Fact-Checking Network \\
(IFCN).
\end{tabular}

